\title{
REVIEWS
}

Adv Clin Exp Med 2014, 23, 4, 657-663

(c) Copyright by Wroclaw Medical University ISSN 1899-5276

Katarzyna ZabŁocka-SŁowińska, A-D, Katarzyna JawnA ${ }^{2, A-D}$, Halina Grajeta ${ }^{1, \mathrm{E}, \mathrm{F}}$, JADWiga Biernat ${ }^{3, \mathrm{~A}, \mathrm{E}, \mathrm{F}}$

\section{Interactions Between Preparations Containing Female Sex Hormones and Dietary Supplements}

${ }^{1}$ Department of Food Science and Nutrition, Wroclaw Medical University, Poland

2 Students' Scientific Club at the Department and Chair of Bromatology and Dietetics,

Wroclaw Medical University, Poland

${ }^{3}$ Department of Human Nutrition, Wroclaw University of Life Sciences, Poland

A - research concept and design; $\mathbf{B}$ - collection and/or assembly of data; C - data analysis and interpretation;

$\mathbf{D}$ - writing the article; $\mathbf{E}$ - critical revision of the article; $\mathbf{F}$ - final approval of article; $\mathbf{G}$ - other

\begin{abstract}
An increasing number of premenopausal women use contraception whereas postmenopausal women use hormone replacement therapy (HRT). This long-term hormone therapy poses a high risk of interactions with dietary supplements. Taking estrogens at the same time as selective estrogen receptor modulators (SERMs), biologically-active compounds of glycine soja, Ginkgo biloba or Pimpinella anisum, may distort the final effect of the hormone agent. On the other hand, estrogen therapy coupled with melatonin or retinol supplementation may lead to an increased level of dietary supplements in the serum as studies have proved a concomitant beneficial effect of HRT and vitamin E supplementation on lipid profiles. In turn, taking preparations containing St John's wort during hormone therapy may lead to a reduction in hormone concentrations in serum and debilitation of the pharmacological effect. It results from the inductive effect of the biologically-active compounds of St John's wort on the metabolism of hormones as a result of the enhanced activity of cytochrome P450 CYP3A4 (Adv Clin Exp Med 2014, 23, 4, 657-663).
\end{abstract}

Key words: dietary supplements, interactions, hormone replacement therapy, contraception.

Preparations containing a female sex hormone are mostly used by women at childbearing age as a method of contraception, or by postmenopausal women as a hormone replacement therapy (HRT). Although HRT is considered a risk factor of breast cancer and other diseases and though its use has declined $[1,2]$, it is still taken by a high percentage of women [3]. A HORTPOL 2002 study has shown that about $12 \%$ of Polish women aged $45-$ -64 used HRT and $64 \%$ of them had it prescribed as an oral medication [4]. According to the Central Statistics Office, in 2009 about 30\% of women aged 15-50 years and using birth control chose hormonal contraception via pills, patches, or injections [5]. Hormone therapy is constantly transforming in terms of doses, types of hormones, and schedule of their administration $[6,7]$. Hormone replacement therapy or hormonal contraception are commonly continued for a long time. It can lead to the risk of an interaction not only with other drugs, but also with ingredients of dietary supplements. Dietary supplement usage is high and still increasing in many countries [8-10]. Their popularity varies depending on age, gender, living place, and educational level. Much more women than men take these preparations and also more women at the perimenopausal or postmenopausal age, especially with a higher educational level than younger women $[11,12]$.

The aim of this study was to review published studies concerning the interactions between drugs containing female sex hormones and dietary supplements. 


\section{Estrogen Receptors and Selective Estrogen Receptor Modulators}

Estrogens act on the body via two subtypes of intracellular estrogen receptors, alpha $(\mathrm{ER} \alpha)$ and beta $(\mathrm{ER} \beta)$, which occur in different organs [13]. They function mainly as transcription factors but estrogen-regulated cells also contain membrane receptors linked to a protein $G$, which are responsible for rapid non-genomic estrogen activity. This signalization is also connected with, i.a., activation of Src kinases, PI3K/Akt kinases and MAPK/ERK, and stimulation of nitric oxide (NO) production by endothelial nitric oxide synthase (eNOS) [14-16].

Selective estrogen receptor modulators (SERMs) are a group of substances with estrogenlike effects. Among others, they include phytoestrogens, which occur naturally in some plants and are divided into three basic groups:

- isoflavones (found mainly in soybean, and in soy products),

- lignans (found in cereals, flax seeds, vegetables and fruits),

- coumestans (found in alfalfa sprouts and various kinds of beans) [17-19].

They differ from natural hormones in that they cause only a part of the estrogenic activity without showing other activities typical of these hormones. This is probably due to the different affinity of the two estrogen receptor subtypes ( $\alpha$ and $\beta$ ), or from a differentiated structure of the ligand-estrogen receptor complexes, particularly differences in the structure of the trans-activating domains that occur during the binding of estrogen and SERMs [20,21].

Phytoestrogens exhibit various estrogen-like effects, depending on cell type, target organ, endogenous estrogen concentration and receptor expression. These compounds exhibit a much higher affinity to the estrogen receptor beta than alpha. Phytoestrogens exert both positive and negative effects on the body. They can decrease the risk of development of many diseases, but also may interfere with the proper functioning of the reproductive system and can interact with medicines containing female sex hormones [21-23].

\section{Interactions Between Preparations Containing Female Sex Hormones and SERMs}

Soybean (Glycine hispida, Glycine soja) is one of the most important dietary sources of phytoestrogens. Its beans contain high amounts of isoflavones with estrogenic activity: daidzein, genistein and glycitein. Dietary supplementation of soy isoflavones may reduce menopausal symptoms and moreover breast cancer risk [24]. It has been shown that women taking a diet rich in soy protein (source of isoflavones) had significantly reduced urinary levels of the sex hormones estradiol, estrone and estriol, compared to women applying the conventional diet. Soy phytoestrogens reduce endogenous estrogen synthesis by inhibiting the activity of key enzymes involved in their metabolism - aromatase and dehydrogenases [25]. Suparto et al. [26] conducted a study with 40 monkeys administered an atherogenic diet for 15 months. The animals were divided into four groups: the first received casein as a protein source, the second - casein and hormone therapy (5 mg ethinylestradiol $+1 \mathrm{mg}$ of norethindrone per day), the third - soy protein providing $141 \mathrm{mg}$ isoflavones per day, and the fourth - soy protein and hormone therapy. After a year of the study, myocardial infarction was induced in the animals. The heart necrosis area was significantly larger $(55 \%)$ in the fourth group compared to the other groups of animals (approximately 30\%). The mechanism of this interaction is unclear, but the authors suggest that it may be related to the adverse effect of soy isoflavones on cardiac hemodynamics, especially during hormone therapy.

An extract from the leaves of Ginkgo biloba (GBE) also contain phytoestrogens. Kaempferol, quercetin and isorhamnetin are the most important flavonoids of G. biloba leave extract. SeungMin et al. [27] investigated the estrogenic activity of these major components of GBE. They showed that the biologically-active compounds affected both the estrogen receptors $\alpha$ and $\beta$, but the affinity for ER $\beta$ was greater than for ER $\alpha$. The results also suggest that these components induced pS2 gene transcription and PR (progesterone receptor) in MCF-7 human breast cancer. The authors suggest that the estrogen-like potential of the biologically-active compounds present in GBE can be used in the future as an alternative to hormone replacement therapy. However, further studies are needed to evaluate the physiological impact of GBE on estrogen receptors and possible interactions between hormone therapy and dietary supplements containing GBE.

Anise (Pimpinella anisum) is a plant whose fruits are used to give relief from abdominal pain, intestinal colic and flatulence due to their carminative, choleretic and antispasmodic activity. The main components of anise oil are trans-anethole, limonene, and estragole [28]. A study by Tabanca et al. [29] showed that an essential oil of Pimpinella 
spp. fruits displayed estrogenic activity ranging from $8.3 \times 10^{-8}$ to $1.2 \times 10^{-6}$ (depending on plant species) as compared to $17 \beta$-estradiol. The median therapeutically-effective dose ranged from $45 \mathrm{mg}$ to $650 \mathrm{mg}$. In vitro studies carried out by Kassi et al. [30] suggest that an aqueous extract of anise can also stimulate osteoblast differentiation and express antiestrogenic activity against breast cancer cells.

No studies have been conducted so far on the interaction between the active ingredients of ginkgo and anise and hormonal preparations (contraceptives, hormone replacement therapy). However, the same site of action of the hormones and compounds of these plants can lead to their interaction as a result of competition for the estrogen receptor, which can affect the expected effect.

\section{Interactions Between Preparations Containing Female Sex Hormones and Other Components of Dietary Supplements}

\section{Melatonin}

Melatonin is a biogenic substance the release of which is regulated by circadian rhythm. The amount of synthesized and released melatonin increases at night. It is involved in regulation of the sleep-wake rhythm and mood, and is implicated in causing a hypnotic effect through the activation of membrane-integrated melatonin receptors [31]. In Poland, melatonin has been available as an OTC drug prescribed in sleep disturbances caused by shift work, changing time zones or blindness. Currently it is also a component of dietary supplements. Components of hormonal contraceptives, e.g. estrogens, can increase serum melatonin concentration, which has been shown in clinical surveys conducted by Hilli et al. [32]. These authors observed that women taking oral contraceptives had an increased melatonin bioavailability: a 4-5-fold increase in the maximum concentration $\left(\mathrm{C}_{\max }\right)$ and in the area under the curve (AUC). Elevated serum levels of melatonin had a negative impact on attention and concentration at work, and increased daytime sleepiness. CYP1A2 is the main isoenzyme of cytochrome P450 which metabolizes melatonin and for which ethinyl estradiol is a moderate inhibitor. Melatonin supplementation during hormonal therapy should always be taken with caution and consulted with a physician.

The biologically-active components of St. John's wort herb (Hypericum perforatum) may affect the pharmacokinetics of desogestrel, ethinyl estradiol and norethisterone. Heavy bleeding during the menstrual cycle as well as an increased risk of unwanted pregnancies were observed in women taking St. John's wort preparations during hormone contraception [33-35].

Pfrunder et al [33] conducted a study among 17 healthy women using a contraception containing ethinylestradiol and desogestrel (20/150 mg/ day) and preparation of St. John's wort (900 mg/ day). They observed breakthrough bleeding in $80 \%$ of the recruited women, while only $35 \%$ of the women had these adverse symptoms before the study. In addition, they found that supplementation with St. John's wort altered the pharmacokinetics of 3-ketodesogestrel - the active metabolite of desogestrel, which was manifested by a reduction of $\mathrm{C}_{\max }$ (about $23 \%$ ) and AUC (about 42\%), but had no effect on the bioavailability of ethinylestradiol [33].

In turn, Hall et al. [34] demonstrated changes in the pharmacokinetics of ethinylestradiol manifested in a reduced half-life of this hormone (23.4 h vs. $12.2 \mathrm{~h}$ ). The authors also reported a decreased bioavailability of norethisterone expressed by increased clearance of the drug (8.2 l/h vs. $9.5 \mathrm{l} / \mathrm{h})$. Serum concentrations of luteinizing hormone (LH), follicle stimulating hormone (FSH) and progesterone were unchanged. A major problem appeared to be breakthrough bleeding, which was the main reason for discontinuation of hormonal contraception among the respondents. In a study by Murphy et al. [35] conducted among 16 women using oral hormonal contraception, significant changes were observed in the pharmacokinetics of norethindrone and ethinylestradiol in the women taking 900 mg of St. John's Wort extract/day. The authors reported a significant decrease in AUC and a significant increase in clearance of the analyzed hormones. In addition, three women had increased levels of serum progesterone (> $3 \mathrm{ng} / \mathrm{mL}$ ), which was indicative of ovulation.

The biologically-active components of St. John'swort may induce the metabolism of contraceptive hormones due to enhancement of the activity of the cytochrome P450 isoenzyme - CYP3A4, and thereby lead to a reduction in hormone concentration and debilitation of the pharmacological effect. Hyperforin, the main active ingredient in St. John's wort, is probably responsible for the induction of the cytochrome P450 isoenzyme [33-35].

\section{Vitamins and Other Antioxidant Substances}

The rapid pace of life, overwork, bad eating habits and a stressful life are the most important factors influencing a large increase in the use of 
dietary supplements [36]. Products containing antioxidants - carotenoids and vitamins A, C and $\mathrm{E}$ are of particular interest to consumers. These substances are involved in preventing the occurrence of oxidative stress in the body and prevent several stress-related diseases although dietary supplementation may increase risk for some types of cancer [10,37].

Vihtamaki et al. [38] assessed the interactions between ascorbic acid (vitamin C) and hormone replacement therapy in postmenopausal women. The study was comprised of 25 healthy women using a transdermal gel with estradiol for the 10-12 months prior. The women were supplemented with $1000 \mathrm{mg}$ of vitamin $\mathrm{C}$ per day and continued hormone therapy. After a month of vitamin C supplementation, the authors observed increased serum estradiol levels by an average of $20.8 \%$, and, in women with initially low levels of vitamin $\mathrm{C}(<70 \mathrm{mmol} / \mathrm{L})$, up to $55 \%$.

In the 1970's, Yeung [39] observed a significantly higher concentration of serum retinol in women taking hormone therapy compared to those that had never applied it. In 2002, Thane et al. [40] evaluated the nutritional status of 117 women aged 16-18 years. 39 of the recruited women were taking oral contraceptives. Women taking hormonal preparations had about $28 \%$ higher concentrations of serum retinol than women who did not use hormonal contraception. Increased, estrogeninduced synthesis of retinol-binding protein (RBP) in the liver was probably the reason for this elevated serum retinol concentration. Women taking hormonal contraception or hormone replacement therapy should not supplement their diet with high doses of vitamin A, to avoid excessive retinol accumulation in their body.

Wander et al. [41] evaluated the effect of dietary supplementation with alpha-tocopherol acetate and fish oil on the oxidative susceptibility of low-density lipoprotein (LDL) in women after menopause. The study involved 48 women, half of whom were using HRT. All women were given fish oil at a dose of $15 \mathrm{~g} /$ day, and alpha-tocopherol acetate in the following doses: 0, 100, 200 or 400 $\mathrm{mg} /$ day. Dietary supplementation with fish oil only slowed down the propagation of LDL cholesterol oxidation in women using and not using HRT. In addition, supplementation with tocopherol increased the initiation time of LDL oxidation (even at the lowest dose applied), but there was no significant effect on the rate of propagation and the concentration of the diene as compared to the group supplemented with only fish oil. These authors observed a faster rate of propagation and higher $\mathrm{C}_{\max }$ of the dienes in the group of women not using HRT compared to women applying HRT. The combined use of tocopherol acetate and fish oil increased the resistance of LDL to oxidation. This beneficial effect of dietary supplementation can be used to potentiate the positive effects of HRT on the lipid profile in postmenopausal women.

The level of sex hormone-binding protein (SHBP) increases, e.g., when using hormone therapy (HRT, contraception) and during oral combined administration of hormone contraceptives, especially with third generation progestagen and ethinylestradiol $[42,43]$. Nayeem et al. [44] examined the relationship between diet, anthropometric and biochemical parameters and the concentration of SHBG in a group of 255 healthy premenopausal women (30-40 years). The authors showed a positive correlation between SHBG and HDL-cholesterol or progesterone as well as increased levels of SHBG during $\beta$-tocopherol and linoleic acid supplementation. Concomitant use of hormone therapy and $\beta$-tocopherol or linoleic acid supplementation may lead to an uncontrolled increase of SHGB concentration.

\section{Minerals}

Taking mineral supplementation during hormonal therapy may lead to mineral metabolism disturbances because hormonal contraception and hormonal replacement therapy can change mineral bioavailability. Akinloye et al. [45] conducted a study focusing on the influence of hormonal contraceptives on serum trace elements, phosphorus and calcium levels. The authors recruited 100 women using different contraceptive methods: 50 on oral contraception, 25 on injectable contraception and 25 on an intra-uterine method, and also 50 non-contraceptive users as a control group. They found significantly lower serum levels of zinc ( 0.70 vs. $1.00 \mathrm{mg} / \mathrm{dL})$, selenium (74.52 vs. $89.68 \mu \mathrm{g} / \mathrm{L})$, phosphorus ( 2.75 vs. $3.31 \mathrm{mg} / \mathrm{dL}$ ) and magnesium ( $1.84 \mathrm{vs.} 2.05 \mu \mathrm{g} / \mathrm{L})$ in participants taking hormonal contraceptives than in the control group. However, the mean serum iron, copper $(98.64$ vs. $89.80,1.69$ vs. $0.98 \mu \mathrm{g} / \mathrm{L})$ and calcium ( 2.43 vs. $2.10 \mathrm{mg} / \mathrm{dL}$ ) concentrations were significantly higher in women taking hormonal contraceptives when compared with the control group. Beneš et al. [46] also found that hormonal contraception significantly increased blood copper concentration. Estrogens can lead to enhanced ceruloplasmin synthesis in the liver, which causes higher copper concentration in the blood. In Beneš'study, in contrast to Akinloye et al. [49] observations, hormonal contraception did not influence blood selenium and zinc concentrations. Bureau et al. [47] conducted a study on 44 postmenopausal women. 
Eighteen of them were treated with HRT, The remaining women were the control group. These authors observed higher mean plasma copper and chromium concentrations in the group of women using HRT than in the control group. They also found that urinary secretion of chromium, magnesium and zinc was decreased in the hormone-treated women group in comparison to the control group. Concomitant hormonal therapy and dietary supplementation with these minerals may lead to an uncontrolled increase of these elements' concentration.

\section{Summary}

A substantial increase in the number of women using hormonal preparations and frequent dietary supplementation poses a risk of interactions between hormones and the ingredients of dietary supplements. For effective and safe hormone therapy, it is important to achieve and maintain adequate serum hormone concentrations. A multitude of factors disrupting the balance of hormones, including nutritional factors, indicates the need for raising awareness on the interactions between hormones and components of dietary supplements. On the other hand, hormone therapy can also influence nutritional status, which has been observed in many studies. Knowledge of the mutual influence of hormones and dietary supplements should be continuously verified, mainly due to the emergence of an increasing number of studies. However, no studies have been conducted so far on the concomitant use of many ingredients of dietary supplements with hormones, so it is recommended rather to avoid the simultaneous intake of hormone preparations and dietary supplements.

\section{References}

[1] Bakken K, Fournier A, Lund E, Waaseth M, Dumeaux V, Clavel-Chapelon F, Fabre A, Hemon B, Rinaldi S, Chajes V, Slimani N, Allen NE, Reeves GK, Bingham S, Khaw K-T, Olsen A, Tjonneland A, Rodriguez L, Sánchez MJ, Etxezarreta AP, Ardanaz E, Tormo MJ, Peeters PH, van Gils CH, Steffen A, Schulz M, Chang-Claude J, Kaaks R, Tumino R, Gallo V, Norat T, Riboli E, Panico S, Masala G, Gonzáles CA, Berrino F: Menopausal hormone therapy and breast cancer risk: impact of different treatments. The European Prospective Investigation into Cancer and Nutrition. Int J Cancer 2011, 128, 144-156.

[2] Mørch LS, Løkkegaard E, Andreasen AH, Kjær SK, Lidegaard Ø: Hormone therapy and different ovarian cancers: a national cohort study. Am J Epidemiol 2012, 175, 1234-1242.

[3] Tsai SA, Stefanick ML, Stafford RS: Trends in menopausal hormone therapy use of US office-based physicians, 2000-2009. Menopause 2011, 18, 385-392.

[4] Rachoń D, Zdrojewski T, Suchecka-Rachoń K, Szpakowski P, Bandosz P, Manikowski A, Wyrzykowski B: Knowledge and use of hormone replacement therapy among Polish women: estimates from a nationally representative study - HORTPOL 2002. Maturitas 2004, 47, 31-37.

[5] Główny Urząd Statystyczny: Stan zdrowia ludności Polski w 2009 r., Warszawa, 2011, 78-79 (Internet: http://www. stat.gov.pl).

[6] Bitzer J, Gemzell-Danielsson K, Roumen F, Marintcheva-Petrova M, van Bakel B, Oddens BJ: The CHOICE study: Effect of counselling on the selection of combined hormonal contraceptive methods in 11 countries. Eur J Contracept Reprod Health Care 2012, 17, 65-78.

[7] Birkhäuser PMH, Reinecke I: Current trends in hormone replacement therapy: perceptions and usage. Climacteric 2008, 11, 192-200.

[8] Stoia M, Oancea S: Herbal dietary supplements consumption in Romania from the perspective of public health and education. Acta Med Transilv 2013, 18, 216-219.

[9] Lentjes MA, Welch AA, Luben RN, Khaw KT: Differences in dietary supplement use and secular and seasonal trends assessed using three different instruments in the EPIC-Norfolk Population Study. J Diet Suppl 2013, 10, $142-151$.

[10] Bailey RL, Gahche JJ, Lentino CV, Dwyer JT, Engel JS, Thomas PR, Betz JM, Sempos CT, Picciano MF: Dietary supplement use in the United States, 2003-2006. J Nutr 2011, 141, 261-266.

[11] Rovira MA, Grau M, Castañer O, Covas MI, Schröder H: Dietary supplement use and health-related behaviors in a Mediterranean population. J Nutr Educ Behav 2012, 45, 386-391.

[12] Timbo BB, Ross MP, McCarthy PV, Lin CTJ: Dietary supplements in a national survey: prevalence of use and reports of adverse events. J Am Diet Assoc 2006, 106, 1966-1974.

[13] Brandenberger AW, Tee MK, Lee JY, Chao V, Jaffe RB: Tissue distribution of estrogen receptors alpha (ER- $\alpha$ ) and beta (ER- $\beta$ ) mRNA in the midgestational human fetus. J Clin Endocrinol Metabol 1997, 82, 3509-3512.

[14] Chambliss KL, Wu Q, Oltmann S, Konaniah ES, Umetani M, Korach KS, Thomas GD, Mineo C, Yuhanna IS, Kim SH, Madak-Erdogan Z, Maggi A, Dineen SP, Roland CL, Hui DY, Brekken RA, Katzenellenbogen JA, Katzenellenbogen BS, Shaul PW: Non-nuclear estrogen receptor a signaling promotes cardiovascular protection but not uterine or breast cancer growth in mice. J Clin Invest 2010, 120, 2319-2330.

[15] Hogan AM, Collins D, Sheehan K, Zierau O, Baird AW, Winter DC: Rapid effects of phytoestrogens on human colonic smooth muscle are mediated by oestrogen receptor $\beta$. Mol Cell Endocrinol 2010, 320, 106-110. 
[16] Maggiolini M, Vivacqua A, Fasanella G, Recchia AG, Sisci D, Pezzi V,Montanaro D, Musti AM, Picard D, Andò S: The G protein-coupled receptor GPR30 mediates $\mathrm{c}$-fos up-regulation by $17 \beta$-estradiol and phytoestrogens in breast cancer cells. J Biol Chem 2004, 279, 27008-27016.

[17] Steinberg FM, Murray MJ, Lewis RD, Cramer MA, Amato P, Young R, Barnes S, Konzelmann KL, Fisher JG, Ellis KJ, Shypailo RJ, Fraley JK, Smith EO, Wong WW: Clinical outcomes of a 2-y soy isoflavone supplementation in menopausal women. Am J Clin Nutr 2011, 93, 356-367.

[18] Saggar JK, Chen J, Corey P, Thompson LU: Dietary flaxseed lignan or oil combined with tamoxifen treatment affects MCF-7 tumor growth through estrogen receptor- and growth factor-signaling pathways. Mol Nutr Food Res 2010, 54, 415-425.

[19] Hong YH, Wang SC, Hsu C, Lin BF, Kuo YH, Huang C. Phytoestrogenic compounds in alfalfa sprout (Medicago sativa) beyond coumestrol. J Agric Food Chem 2010, 59, 131-137.

[20] Jiang Y, Gong P, Madak-Erdogan Z, Martin T, Jeyakumar M, Carlson K, Khan I, Smillie TJ, Chittiboyina AG, Rotte SCK, Helferich WG, Katzenellenbogen JA, Katzenellenbogen BS: Mechanisms enforcing the estrogen receptor $\beta$ selectivity of botanical estrogens. The FASEB Journal 2013, 27, 4406-4418.

[21] Sotoca AM, Gelpke MDS, Boeren S, Ström A, Gustafsson JÅ, Murk AJ, Rietjens IMCM, Vervoort J: Quantitative proteomics and transcriptomics addressing the estrogen receptor subtype-mediated effects in T47D breast cancer cells exposed to the phytoestrogen genistein. Mol Cell Proteom 2011, 10, M110.002170. DOI: 10.1074/mcp. M110.002170.

[22] Losa SM, Todd KL, Sullivan AW, Cao J, Mickens JA, Patisaul HB: Neonatal exposure to genistein adversely impacts the ontogeny of hypothalamic kisspeptin signaling pathways and ovarian development in the peripubertal female rat. Reprod Toxicol 2011, 31, 280-289.

[23] Gaete L, Tchernitchin AN, Bustamante R, Villena J, Lemus I, Gidekel M, Cabrera G, Astorga P: Daidzein-estrogen interaction in the rat uterus and its effect on human breast cancer cell growth. J Med Food 2012, 15, 1081-1090.

[24] Kang HB, Zhang YF, Yang JD, Lu KL: Study on soy isoflavone consumption and risk of breast cancer and survival. Asian Pac J Cancer Prev 2012, 13, 995-998.

[25] Xu X, Duncan AM, Merz BE, Kurzer MS: Effects of soy isoflavones on estrogen and phytoestrogen metabolism in premenopausal women. Cancer Epidemiol Biomarkers Prev 1998, 7, 1101-1108.

[26] Suparto IH, Williams JK, Fox JL, Yusuf JTL, Sajuthi D: Effects of hormone therapy and dietary soy on myocardial ischemia/reperfusion injury in ovariectomized atherosclerotic monkeys. Menopause 2008, 15, 256-263.

[27] Sueng-Min O, Kyu-Hyuck C: Estrogenic activities of Ginkgo biloba extracts. Life Sci 2004, 74, 1325-1335.

[28] Hassan WN, Saed AM: Protective effect of Anise Fruit (Pimpinella anisum) against osteoporosis in rat model. Am J Biomed Sci 2011, 3, 49-56.

[29] Tabanca N, Khan SI, Bedir E, Annavarapu S, Willett K, Khan IA, Kirimer N, Baser KH: Estrogenic activity of isolated compounds and essential oils of Pimpinella species from Turkey, evaluated using a recombinant yeast screen. Planta Med 2004, 70, 728-735.

[30] Kassi E, Papoutsi Z, Fokialakis N, Messari I, Mitakou S, Moutsatsou P: Greek plant extracts exhibit selective estrogen receptor modulator (SERM)-like properties. J Agric Food Chem 2004, 52, 6956-6961.

[31] Ochoa-Sanchez R, Rainer Q, Comai S, Spadoni G, Bedini A, Rivara S, Fraschini F, Mor M, Tarzia G, Gobbi G: Anxiolytic effects of the melatonin MT2 receptor partial agonist UCM765: Comparison with melatonin and diazepam. Prog Neuro-Psychopharmacol Biol Psych 2012, 39, 318-325.

[32] Hilli J, Korhonen T, Turpeinen M, Hokkanen J, Mattila S, Laine K: The effect of oral contraceptives on the pharmacokinetics of melatonin in healthy subjects with CYP1A2 polymorphism. J Clin Pharmacol 2008, 48, 986-994.

[33] Pfrunder A, Schiesser M, Gerber S, Haschke M, Bitzer J, Drewe J: Interaction of St John's wort with low-dose oral contraceptive therapy: a randomized controlled trial. Br J Clin Pharmacol 2003, 56, 683-690.

[34] Hall SD, Wang Z, Huang SM, Hamman MA, Vasavada N, Adigun AQ, Hilligoss JK, Miller M, Gorski JC: The interaction between St John's wort and an oral contraceptive. Clin Pharmacol Ther 2003, 74, 525-535.

[35] Murphy PA, Kern SE, Stanczyk FZ, Westhoff CL: Interaction of St John's wort with oral contraceptives: effects on the pharmacokinetics of norethindrone and ethinyl estradiol, ovarian activity and breakthrough bleeding. Contraception 2005, 71, 402-408.

[36] Sigłowa A, Bertrandt B, Conder M, Bertrandt K, Lisiecka A, Kubiak P, Urbańska A: Suplementacja diety wśród studentów. Żywność Nauka Technologia Jakość 2009, 65, 236-249.

[37] Myung SK, Kim Y, Ju W, Choi HJ, Bae WK: Effects of antioxidant supplements on cancer prevention: metaanalysis of randomized controlled trials. Ann. Oncol 2010, 21, 166-179.

[38] Vihtamaki T, Parantainen J, Koivisto AM, Metsa-Ketela T, Tuimala R: Oral ascorbic acid increases plasma oestradiol during postmenopausal hormone replacement therapy. Maturitas 2002, 42, 129-135.

[39] Yeung DL: Effect of oral contraceptives on vitamin A metabolism in the human and the rat. Am J Clin Nutr 1974, 27, 125-129.

[40] Thane CW, Bates CJ, Prentice A: Oral contraceptives and nutritional status in adolescent British girls. Nutr Res 2002, 22, 449-462.

[41] Wander RC, Du S-H, Ketchum S, Rowe KE: Effects of interaction of RRR-a-tocopheryl acetate and fish oil on low-density-lipoprotein oxidation in postmenopausal women with and without hormone-replacement therapy. Am J Clin Nutr 1996, 63, 184-193.

[42] Edlefsen KL, Jackson RD, Prentice RL, Janssen I, Rajkovic A, O'Sullivan MJ, Anderson G: The effects of postmenopausal hormone therapy on serum estrogen, progesterone and sex hormone binding globulin levels in healthy post-menopausal women. Menopause 2010, 17, 622. 
[43] Stegeman BH, Raps M, Helmerhorst FM, Vos HL, van Vliet HAAM, Rosendaal FR, van Hylckama Vlieg A: Effect of ethinylestradiol dose and progestagen in combined oral contraceptives on plasma sex hormone囚binding globulin levels in premenopausal women. J Thromb Haemost 2013, 11, 203-205.

[44] Nayeem F, Nagamani M, Anderson KE, Huang Y, Grady JJ, Lu LJW: Dietary beta-tocopherol and linoleic acid, serum insulin, and waist circumference predict circulating sex hormone-binding globulin in premenopausal women, J Nutr 2009, 139, 1135-1142.

[45] Akinloye O, Adebayo TO, Oguntibeju OO, Oparinde DP, Ogunyemi EO: Effects of contraceptives on serum trace elements, calcium and phosphorus levels. West Indian Med J 2011, 60, 308-315.

[46] Beneš B, Spěváčková V, Šmid J, Batáriová A, Čejchanová M, Zitková L: Effect of age, BMI, smoking and contraception on levels of $\mathrm{Cu}$, Se an $\mathrm{Zn}$ in the blood of the population in the Czech Republic. Cent Eur J Publ Health 2005, 13, 202-207.

[47] Bureau I, Anderson RA, Arnaud J, Raysiguier Y, Favier AE, Roussel AM: Trace mineral status in postmenopausal women: impact of hormonal replacement therapy. J Trace Elem Med Biol 2002, 16, 9-13.

\section{Address for correspondence:}

Katarzyna Zabłocka-Słowińska

Department of Food Science and Nutrition

Wroclaw Medical University

Borowska 211

50-556 Wrocław

Tel.: 0717840207

E-mail: katarzynazablocka0112@gmail.com

Conflict of interest: None declared

Received: 22.04 .2013

Revised: 16.12.2013

Accepted: 23.07.2014 